\title{
Multiple cardiac fatty deposits in a patient with tuberous sclerosis complex
}

\author{
Masahiro Kimura (10 , ${ }^{1}$ Takao Kato, ${ }^{2}$ Kanae Miyake, ${ }^{3}$ Takeshi Kimura ${ }^{2}$
}

${ }^{1}$ Department of Cardiology, Koto Memorial Hospital, Higashiomi, Japan

${ }^{2}$ Department of Cardivascular Medicine, Kyoto University Graduate School of Medicine, Kyoto, Japan

${ }^{3}$ Department of Advanced Medical Imaging Research, Kyoto University Graduate School of Medicine, Kyoto, Japan

Correspondence to Dr Masahiro Kimura; mkimura@kuhp.kyoto-u.ac.jp

Accepted 16 July 2021

Check for updates

(c) BMJ Publishing Group Limited 2021. No commercial re-use. See rights and permissions. Published by BMJ.

To cite: Kimura M, Kato T, Miyake K, et al. BMJ Case Rep 2021;14:e244366. doi:10.1136/bcr-2021244366

\section{DESCRIPTION}

Tuberous sclerosis complex (TSC) is a rare autosomal dominant genetic disease characterised by systemic hamartomas or benign tumours which affects multiple organs including brains, kidneys, heart, liver, eyes, lungs and skin due to inappropriate activation of mammalian target of rapamycin (mTOR) signalling. ${ }^{1}$ About half of patients have multiple cardiac rhabdomyomas during perinatal and early-neonatal period, but most of them would regress after the age of two. Angiomyolipoma (AML) is the most common tumour of the kidney and usually develops from adolescence.

A 55-year-old man with TSC attended to our hospital and had a CT for routine follow-up with renal AML. He had a history of cardiac rhabdomyoma and also had a subependymal hamartomas, liver haemangiomas, adenoma sebaceum of the skin and angiofibroma of toes. During watchful waiting, multiple fatty foci in the heart were detected by CT (figure 1) without any ECG or ultrasonic echocardiography change. Differential diagnosis of the cardiac fatty-containing lesions associated with TSC included fatty replacement after spontaneous remission of rhabdomyomas, ${ }^{2} 3$ or cardiac metastasis of AML. ${ }^{45}$ Then, a cardiac magnetic resonance (CMR) was performed to investigate the tissue characterisations and locations of cardiac lesions (figure 2). The lesions had chemical shift on turbo fast low-angle shot images and exhibited homogeneous high intensity on half-Fourier single-shot turbo spin-echo images, which consisted with they
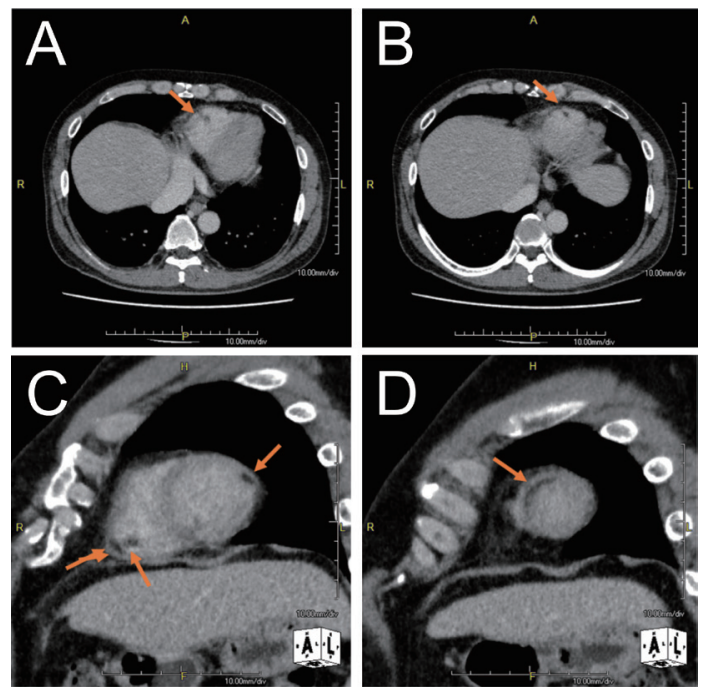

Figure 1 Contrast-enhanced $\mathrm{CT}$ images of cardiac fatty deposits. (A) and (B) are axial planes. (C) and (D) sagittal planes.
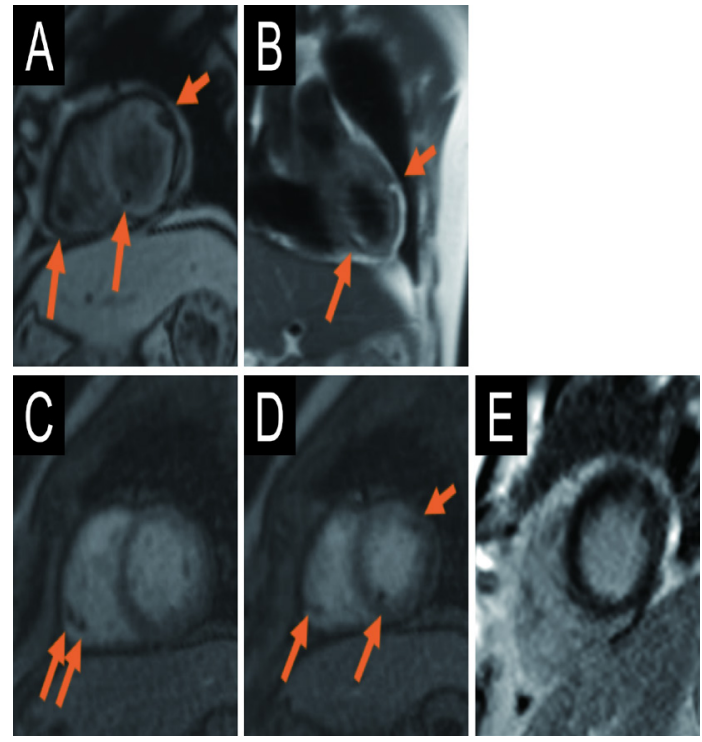

Figure 2 Cardiac MRI images of fatty lesions. (A) Localiser turbo fast low-angle shot image, short axis view. (B) Dark blood half-Fourier single-shot turbo spinecho image, coronal view. (C, D) First-pass myocardial perfusion images, short axis view. (E) Phase sensitive inversion recovery image, short axis view.

being fat. No abnormal enhancement was seen on perfusion images nor late gadolinium enhancement images. CMR suggested all were pure fatty lesions without evidence of residual rhabdomyoma. Most of them were located in the subintimal area of biventricular wall without mass effect, but some of them protruded into cardiac chambers without any blood-flow restriction. Although he had no episode of haemorrhage, pain or renal dysfunction, multiple AMLs in bilateral kidneys had grew slowly and reached to a maximum diameter of $17 \mathrm{~cm}$. Then $5 \mathrm{mg} / \mathrm{kg}$ of everolimus, an mTOR-inhibitor, was administered and CT images revealed significant volume reduction of renal AML, while the size of cardiac masses unchanged.

In our case, CMR was helpful to characterise the cardiac lesions as pure fatty changes, and different response to everolimus between renal AMLs and cardiac lesions indicated an unlikelihood of cardiac metastasis of AML. Though a histological biopsy is required for the definitive diagnosis, it seems impractical to perform due to their focal deposition. CMR also provides detailed information about location and size of fatty deposit, then we concluded the observation strategy was reasonable for cardiac lesions. However, long-term prognosis of this fat-containing change in the heart is still unknown, so careful follow-up is needed. 


\section{Learning points}

Multiple cardiac fatty deposits are sometimes seen in patients with tuberous sclerosis complex and their prognosis is usually benign.

- Cardiac magnetic resonance imaging is useful to characterise lesions and provide locational information of cardiac fatty deposit.

- Evelorimus did not affect cardiac lesions, suggesting the diagnosis of them as fatty replacement of rhabdomyomas and not metastasis of angiomyolipoma.

Contributors MK wrote the manuscript, and TKato, KM and TKimura were supervisors of the manuscript.

Funding The authors have not declared a specific grant for this research from any funding agency in the public, commercial or not-for-profit sectors.
Competing interests None declared.

Patient consent for publication Obtained.

Provenance and peer review Not commissioned; externally peer reviewed.

\section{ORCID iD}

Masahiro Kimura http://orcid.org/0000-0002-9790-4609

\section{REFERENCES}

1 Hinton RB, Prakash A, Romp RL, et al. Cardiovascular manifestations of tuberous sclerosis complex and summary of the revised diagnostic criteria and surveillance and management recommendations from the International tuberous sclerosis consensus group. J Am Heart Assoc 2014;3:e001493.

2 Adriaensen MEAPM, van Oosterhout MFM, Feringa HHH, et al. Mature fat cells in the myocardium of patients with tuberous sclerosis complex. J Clin Pathol 2011;64:244-5.

3 Bakan S, Yahyayev A, Bakan AA, et al. Asymptomatic fatty changes in the myocardium of a patient with tuberous sclerosis. Pediatr Cardiol 2011;32:1216-8.

4 Shaaya EA, Hirshberg JS, Rabe OT, et al. Cardiac fat-containing lesions are common in tuberous sclerosis complex. Am J Med Genet A 2013;161A:1662-5.

5 Winterkorn EB, Dodd JD, Inglessis I, et al. Tuberous sclerosis complex and myocardial fat-containing lesions: a report of four cases. Clin Genet 2007;71:371-3.

Copyright 2021 BMJ Publishing Group. All rights reserved. For permission to reuse any of this content visit

https://www.bmj.com/company/products-services/rights-and-licensing/permissions/

BMJ Case Report Fellows may re-use this article for personal use and teaching without any further permission.

Become a Fellow of BMJ Case Reports today and you can:

- Submit as many cases as you like

- Enjoy fast sympathetic peer review and rapid publication of accepted articles

- Access all the published articles

Re-use any of the published material for personal use and teaching without further permission

\section{Customer Service}

If you have any further queries about your subscription, please contact our customer services team on +44 (0) 2071111105 or via email at support@bmj.com.

Visit casereports.bmj.com for more articles like this and to become a Fellow 